\title{
Stability Evaluation of Slopes Using Kinematic and Limit Equilibrium Analyses in Seismically Active Balakot, KPK, Pakistan
}

\author{
Mian Sohail Akram 1*, Muhammad Fahad Ullah², Faisal Rehman², \\ Muhammad Ali ${ }^{3}$, Luqman Ahmed ${ }^{1}$, Assad Ali Gillani' \\ ${ }^{1}$ Institute of Geology, University of the Punjab, Lahore, Pakistan \\ ${ }^{2}$ Department of Earth Sciences, University of Sargodha, Sargodha, Pakistan \\ ${ }^{3}$ Geological Survey of Pakistan, Quetta, Pakistan \\ Email: *sohail.geo@pu.edu.pk
}

How to cite this paper: Akram, M.S., Ullah, M.F., Rehman, F., Ali, M., Ahmed, L. and Gillani, A.A. (2019) Stability Evaluation of Slopes Using Kinematic and Limit Equilibrium Analyses in Seismically Active Balakot, KPK, Pakistan. Open Journal of Geology, 9, 795-808.

https://doi.org/10.4236/ojg.2019.911091

Received: September 12, 2019

Accepted: October 12, 2019

Published: October 15, 2019

Copyright $\odot 2019$ by author(s) and Scientific Research Publishing Inc. This work is licensed under the Creative Commons Attribution International License (CC BY 4.0).

http://creativecommons.org/licenses/by/4.0/

(c) (i) Open Access

\begin{abstract}
The Northern segment of Pakistan, especially Balakot city is affected up to large extent by the landslides. Tectonically, it lies in the proximity of Hazara Kashmir Syntaxis and other two active regional faults: Main Boundary and Hazara Frontal Thrusts that traversing right through the Balakot town. This study focuses on the evaluation of slopes near Balakot town in static and pseudo-static condition. A geological map is produced at 1:24,000 scale to separate various rock and soil units. During reconnaissance study, two slopes were selected which seem prone to sliding. The procured data on condition of natural slope, properties of material entailed, structural setting, and vegetation cover distribution was gathered. Discontinuity Surveys of slopes were carried out to collect discontinuity parameters. Kinematic analyses were performed on DIPS v. 7.0 to assess mode of failures based on joints data. Limit equilibrium analyses were carried out at Slide v. 7.0 to check factor of safety at different conditions. The study concluded that the slopes were affected by the plane, wedge and toppling failures, while although in seismically active zone, circular failure is not likely.
\end{abstract}

\section{Keywords}

Slope Stability, Kinematic Analysis, Limit Equilibrium Analysis, Roc Science

\section{Introduction}

Earth has a complex structure and due to innumerable phenomena occurring on its surface and interior, disastrous events are likely to happen without any 
warning. Such adverse geological conditions, which are capable of causing damage or loss of property and life, are termed as geological hazard [1] [2] [3]. According to Coppola [4], hazard is the origin of the potential damage to community in which population, infrastructure, inhabitant's property, business and environment are included, for example, it affects human life in the form of injuries, deaths; property damage and social-economic disturbances [5] [6]. Whether it be an earthquake, volcanic activity, tsunami, landslide etc., it is almost difficult to stop such natural events due to their unpredictability [7]. Due to advancement in the field of geology, we are able to understand such events, eventually enabling ourselves to predict them so that the damage can be reduced [3] [8]. The phenomenon of movement of earth material from insignificant to catastrophic level either due to natural or artificial causes is termed as landslide [3] [8] [9]. Lundgren [10] described landslides as the movement of mass of earth, which initiated under the action of the gravitational forces. Singh and Goel [11] termed the advancement of mass of rock or soil in downward and outward directions i.e. the displacement of the mass on a down the hillside or on a sloping ground, as landslide. The nature and intensity of the landslides make them a threat to settlements, infrastructure and communication networks thereby increasing the concern of study and research.

Slope failure is the result of shock e.g. increase in destabilizing force or external load, earthquakes, undermining, cracks in rock with various types such as hair-line cracks, frost wedging, or by increased pressure of water in cracks, clay swelling, excavation and loss of the capillary tension can also become a cause of decrease in shear strength resulting in slope failure [12]. Slope stability analysis can be performed by kinematic analysis, limit equilibrium and numerical modelling techniques. Kinematic analysis is a very useful method to understand types of failure by using discontinuities and joints orientations [13] [14] [15]. Problems related to slope stability can be reduced with refined assessment and detailed examination [16]. The Northern Pakistan has abundance of various types of landslides, which usually occur along major thrusts and road cuts [6] [17]. Many researchers studied landslides in detail to formulate the techniques to rectify and conciliate the issue of landslides [3] [11] [18] [19] [20] [21] [22]. The earthquake, which occurred on October $8^{\text {th }}, 2005$, caused numerous landslides in the Balakot area and this earthquake also activated various landslides in the nearby area [16] [23]-[28].

\section{Study Area}

The area under study comprises of mountainous outcrops covering the city of Balakot, district Mansehra in the province of Khyber Pakhtunkhwa, Pakistan. Balakot city is situated on the banks of River Kunhar before it enters Kashmir Valley. Location map of the study area is given in Figure 1. The city is known to be a tropical area with a good vegetation and forestation cover along steep mountains. This study incorporates the area of Balakot city emphasizing upon 




Figure 1. Location map of selected sites [29].

two landslides; Landslide 1 (LS 1) and Landslide 2 (LS 2) marked on Figure 1 \& Figure 2 [29].

Based on visual observation and slope characteristics, two sites were selected for detailed studies and sites were marked as LS- 1 and LS-2. The outcrops of site LS- 1 lie between longitude and latitude $34^{\circ} 31^{\prime} 39.5^{\prime \prime} \mathrm{N}$ and $73^{\circ} 20^{\prime} 49.1^{\prime \prime} \mathrm{E}$ to $34^{\circ} 31^{\prime} 30.3^{\prime \prime} \mathrm{N}$ and $73^{\circ} 20^{\prime} 43.6^{\prime \prime} \mathrm{E}$, whereas LS-2 lies between $34^{\circ} 31^{\prime} 26.4^{\prime \prime} \mathrm{N}$ and $73^{\circ} 20^{\prime} 42.8^{\prime \prime} \mathrm{E}$ to $34^{\circ} 31^{\prime} 17.1^{\prime \prime} \mathrm{N}$ and $73^{\circ} 20^{\prime} 43^{\prime \prime} \mathrm{E}$.

Rock slope failures in this area mainly triggered after earthquake in 2005. Balakot city was destroyed and rock units seems unstable which caused causalities and damages to infrastructure [25] [28] [30]. The lithological units along the road cut composed of soft rocks as well as high precipitation in the area induce sliding of rock mass along the road.

\section{Geology}

The North-western Himalayas of Pakistan is formed by the collision of plate boundaries [31] [32] [33]. From north to south it is divided as Asian plate, shyok suture zone, Kohistan island arc and Indian plate [32] [34] [35] [36] [37]. Indian 
plate is divided into sub-Himalayas, lesser Himalayas and higher Himalayas bounded by major thrusts. The study area lies close to main boundary thrust $(M B T)$ and Hazara Kashmir Syntaxis, which is a major syntaxial bend of Himalayas. Due to two active regional faults traversing right through the Balakot town, almost entire Balakot city falls in potential hazardous zone. The MBT is passing through North of the Balakot city as Balakot-Bagh thrust (Figure 2) [38].

\section{Geological Map of Balakot and Adjoining Areas, District Mansehra, KPK, Pakistan}



Figure 2. Geological map of study area (reproduced after USGS [38]). 
The Balakot-Bagh thrust is the main identified feature in this zone [26]. Formation observed in the emphasized area is Salkhala Formation. The formation is mainly termed as metamorphosed zone and comprised of Precambrian to Cambrian sequence of quartzite, slates, phyllite, schists and marble [39].

Salkhala Formation of Precambrian age consists of slates with graphitic beds interbedded with marble [38]. It also contains quartzite, quartz schist, garnet-biotite and talc schist at different places. Near Balakot city, this formation thins out and remains to only few hundred meters [40] [41]. It is further divided into two rock units; upper is called as Kundal unit and basal as Gandaf unit [42].

\section{Methodology}

A systematic work methodology was developed in order to study the landslides in Balakot area by employing literature review of previous research especially after earthquake. An overview of the research methodology is giving in Figure 3 and it is explained briefly below. A reconnaissance study carried out to assess the nature of slopes and geology of study area. Geological map demarcating regional faults, rock and soil units was prepared (Figure 2).

Discontinuity Survey were carried out as per standard [43] [44] to assess nature of jointed rock. The parameters such as orientation, spacing, persistence, groundwater conditions and infilling material were used to assess rock quality.

After gathering required data from the sites which seemed to be prone to sliding, the stability analyses of those slopes were conducted by using the empirical classification system, limit equilibrium analysis and kinematic analysis. The parameters which were used in this study are explained in few lines.

For in-situ evaluation of strength of rocks, an indirect tool, the Schmidt

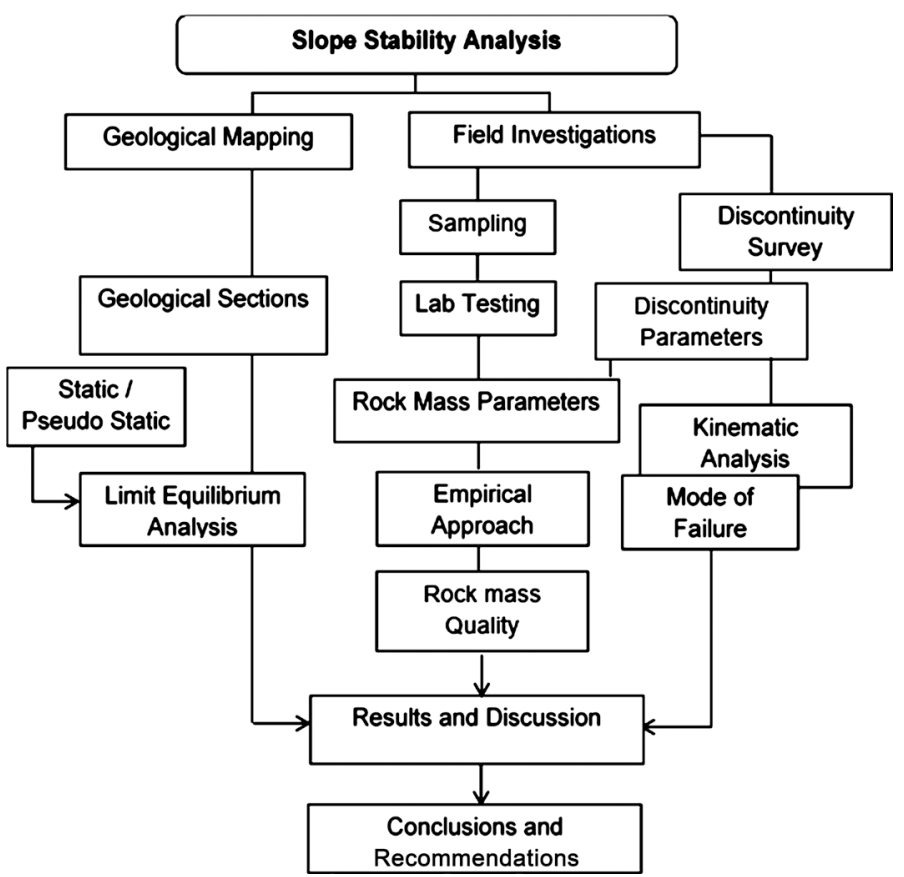

Figure 3. Work methodology flow chart. 
Rebound Hammer was employed in the field. The value of rebound number $(R n)$ was calculated and later it was correlated with the unit weight using correlation chart [43] [44] [45]. Geological strength index (GSI) was calculated by using the correlation given below:

$$
G S I=R M R-5
$$

The GSI value obtained from Equation (1) is one of the input parameters of the analysis using limit equilibrium method. Equation (2) was proposed by Palmström [46] that a correlation can be made for the indirect estimation of Rock Quality Designation (RQD) by using the joint volumetric count $(J v)$. The value of $J_{V}$ represent the sum of reciprocal of all joints which are defined as follows:

$$
J v=1 / S 1+1 / S 2+1 / S 3+\cdots+N R / 5
$$

Here, $S 1, S 2$ and $S 3, \cdots, S n$ represent the spacing of the joints depending on the spacing of joints in rock mass. $N R$ represents the number of the random joints present in the unit and according to Palmström [46] [47] [48] spacing of 5 $\mathrm{m}$ should be used for the random joints.

Procedure of evaluating and predicting the possible direction of moment of rock is called the kinematic analysis [49]. Kinematic analysis is a geometric method, which uses the angular interactions among the discontinuity planes in order to predict the possibility and failure of jointed rock mass unit [50]. Kinematic analysis performed with DIPS v. 7.0 [51], a program of RocScience suite. The limit equilibrium analyses were performed to estimate global failure analysis, factor of safety and surface of failure. By employing the Slide 7.0 (RocScience), limit equilibrium analyses were performed in order to measure the factor of safety (FOS). As discuss earlier, the study area lies in seismically active zone, so to generate a realistic scenario as per field, twenty various analyses were performed in Slide. Analyses were performed in dry to wet condition, whereas the seismic loading of various peak ground acceleration ( $P G A)$ was also employed in the analyses. Four slices methods, Bishop [52], Janbu [53], Corps of Engineers [22], and Spencer [54] [55], were used in these analyses.

\section{Discussions}

Geological map of Balakot city, and adjoining areas having scale 1:24,000 was prepared using satellite images from Google Earth and it was reproduced using ArcGIS 10.3. The major rock units exposed at selected slopes slates and quartzite of Salkhala Formation. The digitized map of Balakot city is given in Figure 2.

Along the road, slided mass was present which caused damaged to retaining structures. Sites that seem unstable and had a chance of landslide were marked and selected for detail studies (Figure 1 and Figure 2). Discontinuity data were conducted on selected sites. Samples were subjected to calculate density with average values ranging from $2.7-3.3 \mathrm{~g} / \mathrm{cm}^{3}$. Schmidt Rebound $(R n)$ values ranges from 15 to 60 so the average strength of rock mass was calculated to be within the range of $84-134 \mathrm{MPa}$ by using the correlation chart [43] [44] [45] [56]. Three 
to four joint sets were observed with closed to moderately space with very low to low persistence and apertures were observed to be as closed to moderately wide.

Empirical classification of rock mass carried out by Rock Mass Rating $(R M R)$ classification system [57] [58] [59] [60]. Table 1 shows that rock mass rating is 62 and 63 for LS1 and LS-2 respectively that falls in good quality.

Kinematic analysis carried out by Dips 7.0 using the orientation data, the LS-1 is likely to have Planar sliding and direct toppling along joint $J 1$ (Figure 4(a)). Flexural toppling is likely to happen along Random joints whereas the wedge sliding is not likely along this slope. On the other hand, LS-2 is likely to have planar sliding and direct toppling along joint $\Omega 1$ and there is probability of wedge failure along $\int 1$ and 2 (Figure $4(\mathrm{~b})$ ). Flexure toppling is likely to occur along the foliation at LS-2. The results of the kinematic analyses are summarized in Table 2. The results of kinematic analyses confirm the field observations as well.

The limit equilibrium analyses were performed for global failure analysis, factor of safety (FOS) and surface of failure. By employing the Slide 7.0 (RocS cience) software, analyses were performed in dry to wet condition, whereas the seismic loading of 0.32 peak ground acceleration $(P G A)$ and under extreme conditions using both wet and PGA.

For the LS-1, in existing conditions, Bishop, Janbu, Spencer and Corps of Engineer method calculated FOS is 5.932, 6.049, 6.125 and 6.098 respectively. Whereas in wet conditions with $10 \mathrm{~m}$ ground water level and $70 \%$ saturation,

Table 1. Rock mass rating of slopes in study area.

\begin{tabular}{|c|c|c|c|c|c|c|c|c|c|c|c|c|}
\hline \multirow{2}{*}{ Site No } & \multicolumn{9}{|c|}{ Ratings of Parameters of Rock Mass Rating } & \multirow{2}{*}{ RMR } & \multirow{2}{*}{ Quality } & \multirow{2}{*}{ GSI } \\
\hline & Strength & RQD & Spacing & Cor & ndit & ion 0 & f Jo & ints & Water Condition & & & \\
\hline LS-1 & 7 & 13 & 10 & 2 & 1 & 5 & 4 & 5 & 15 & 62 & Good Rock & 57 \\
\hline LS-2 & 12 & 13 & 8 & 2 & 1 & 3 & 4 & 5 & 15 & 63 & Good Rock & 58 \\
\hline
\end{tabular}

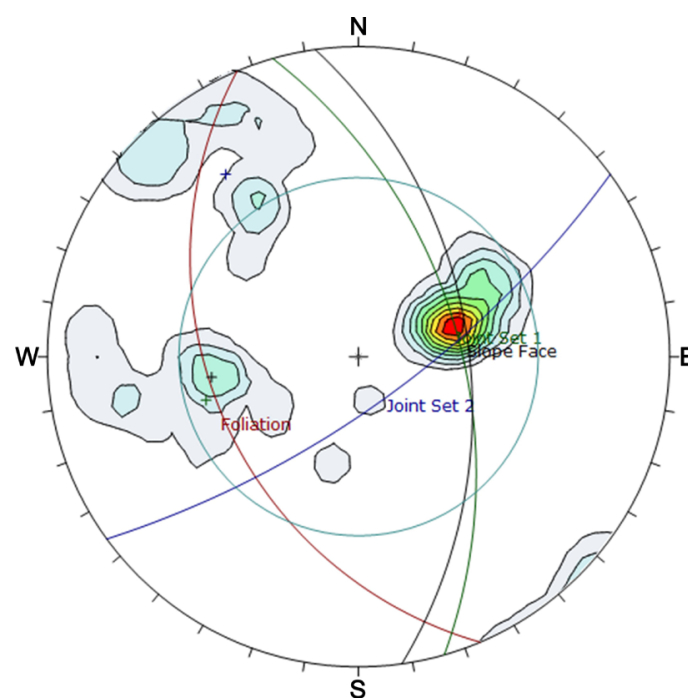

(a)

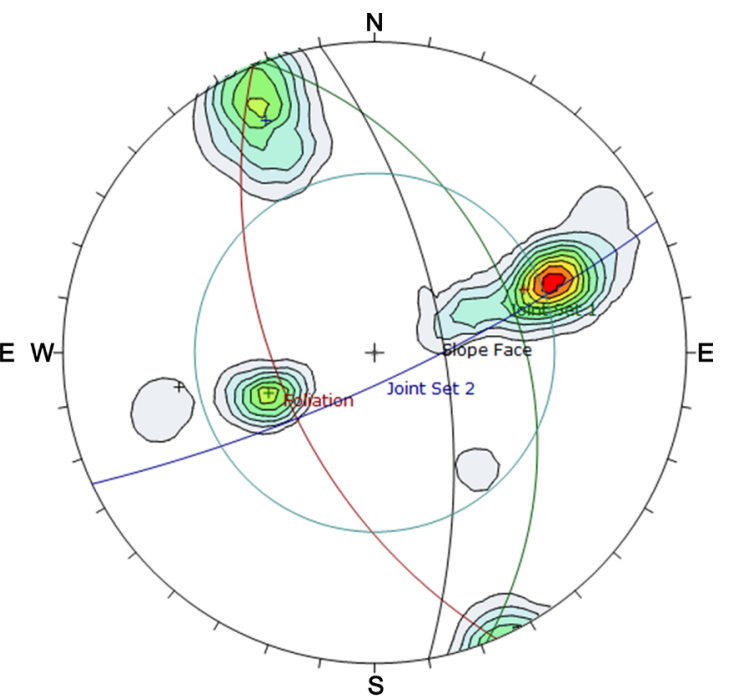

(b)

Figure 4. Kinematic analyses of slopes (a) Landslide-1; (b) Landslide-2. 
FOS is 6.919, 6.949, 7.044 and 7.238. With maximum seismic loading where the $P G A$ was set as 0.32 , the results for aforementioned methods were, 4.205, 3.854, 4.569 and 3.691. In extreme conditions, where the $P G A$ is 0.32 along with presence of water, Bishop, Janbu, Spencer and Corps of Engineer \#1 methods calculated FOS as 4.69, 4.278, 5.079 and 4.458 respectively (Figure 5).

Table 2. Summary of results based on kinematic analyses.

\begin{tabular}{cccc}
\hline \multicolumn{2}{c}{ Kinematic Analysis } & LS-1 & LS-2 \\
\hline \multirow{2}{*}{ Slope Face (Orientation) } & Dip & 51 & 65 \\
& Dip Direction & 081 & 080 \\
Planar Sliding & Likely along J1 & Likely along J1 \\
Wedge Sliding & Not likely & Likely along J1 \& J2 \\
Flexural Toppling & Likely along Random Joints & Likely along Foliation \\
Direct Toppling & Likely along J1 & Likely along J1
\end{tabular}

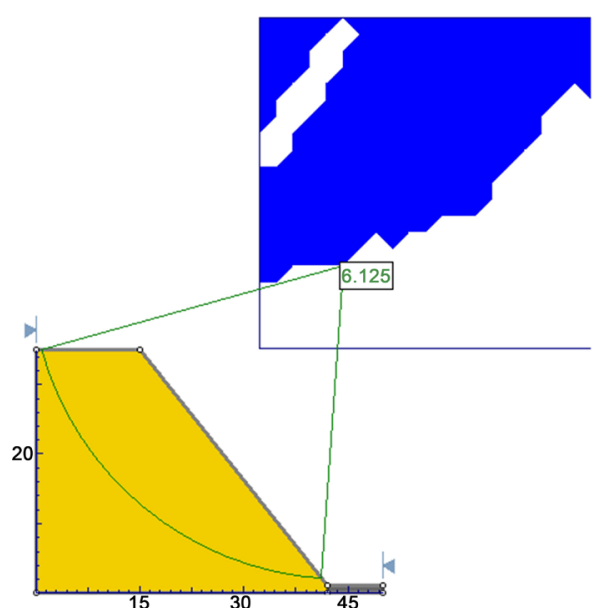

(a) Existing Conditions

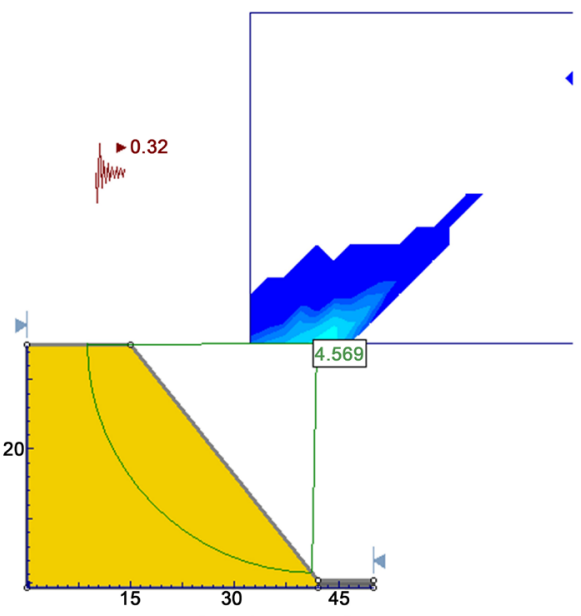

(c) Seismic Loading

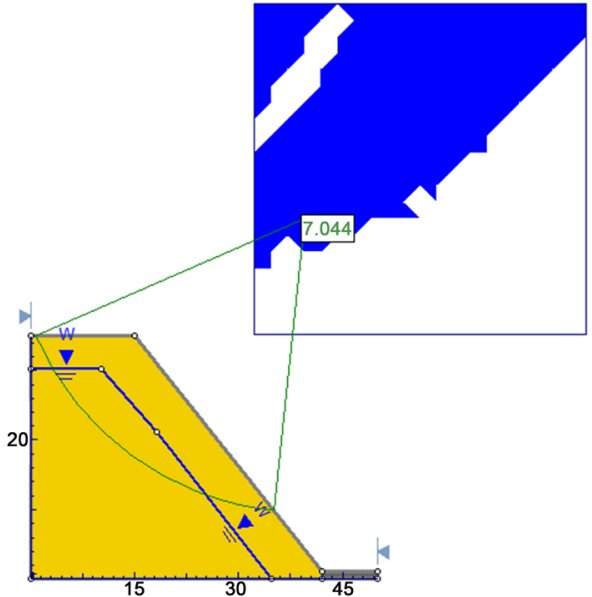

(b) Water Table

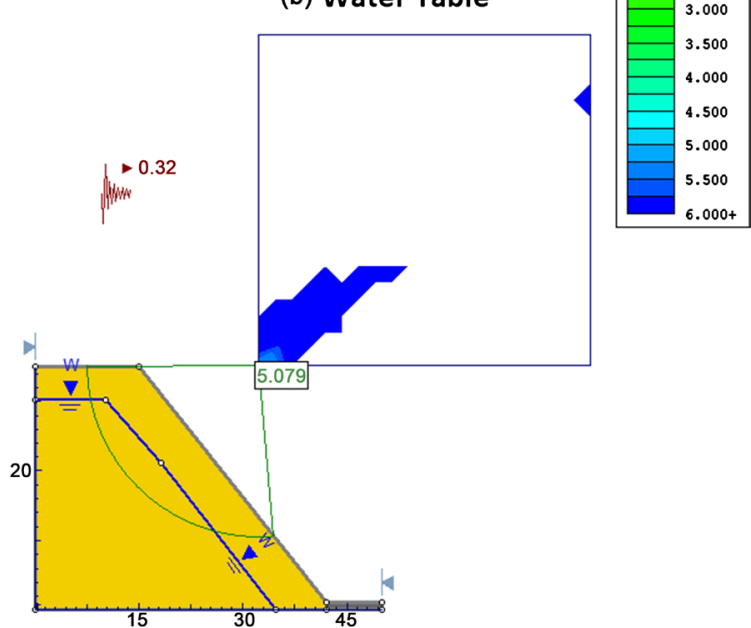

(d) Extreme Conditions

Figure 5. Limit equilibrium analyses of LS-1 using Spencer slice method (a) under normal existing condition of slope (b) water table at $10 \mathrm{~m}$ with $70 \%$ saturation (c) seismic loading at 0.32 peak ground acceleration $(P G A)(\mathrm{d})$ under extreme condition with $10 \mathrm{~m}$ ground water and 0.32 PGA. 
At LS-2, in dry and existing conditions, FOS for Bishop, Janbu, Spencer and Corps of Engineer methods turned out to be 5.932, 6.049, 6.125 and 6.098 respectively. In wet conditions, FOS values were 5.932, 6.049, 6.125 and 6.098 for aforementioned methods. With the maximum seismic loading of 0.32 PGA, FOS values were 4.205, 3.854, 4.569 and 3.961 for Bishop, Janbu, Spencer and Corps of Engineer methods respectively. In the extreme conditions, the values of FOS for Bishop, Janbu, Spencer and Corps of Engineer methods were 4.205, 3.854, 4.569 and 3.961 respectively (Figure 6). FOS values obtained through all the analyses, despite extreme conditions, came out to be greater than 1 (Table 3) which means that the slopes are safe from failure.

\section{Conclusions}

The current study focuses on evaluation of slopes in static and pseudo-static condition, as Balakot lies in a tectonically active regime. During the field excursion,

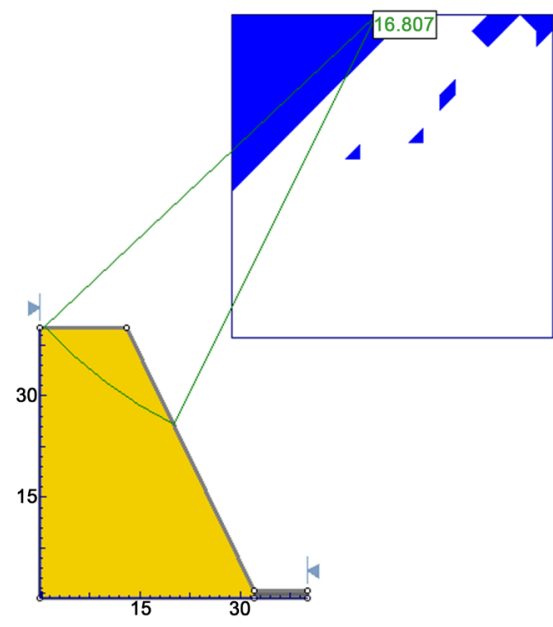

(a) Existing Conditions

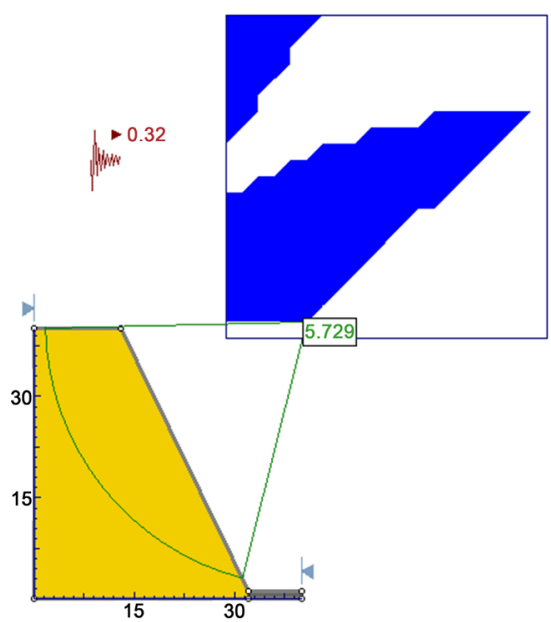

(c) Seismic Loading



(b) Water Table

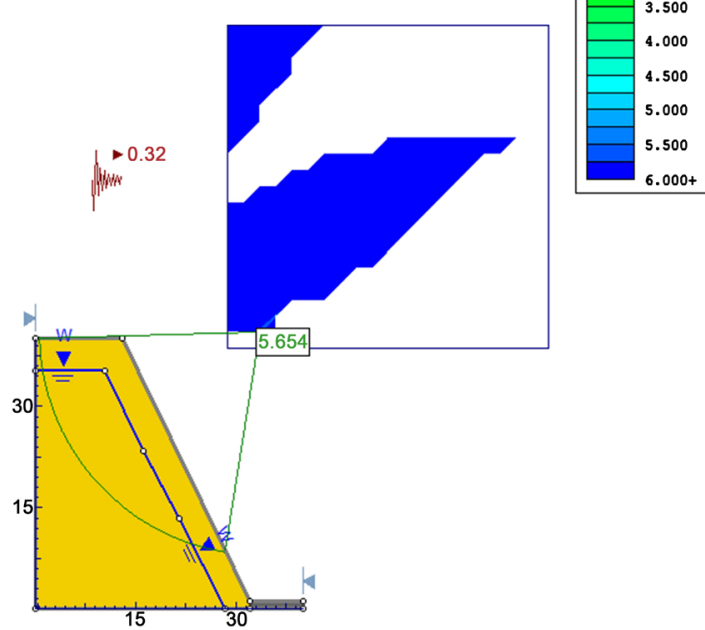

(d) Extreme Conditions

Figure 6. Limit equilibrium analyses of LS-2 using Spencer slice method (a) under normal existing condition of slope (b) water table at $10 \mathrm{~m}$ with $70 \%$ saturation (c) seismic loading at 0.32 -peak ground acceleration (PGA) (d) under extreme condition with 10. 
Table 3. Results of factor of safety (FOS) using limit equilibrium slices method.

\begin{tabular}{|c|c|c|c|c|c|}
\hline $\begin{array}{c}\text { Landslide } \\
\text { No. }\end{array}$ & Condition & $\begin{array}{c}\text { Bishop } \\
\text { Simplified }\end{array}$ & $\begin{array}{c}\text { Janbu } \\
\text { Simplified }\end{array}$ & Spencer & $\begin{array}{l}\text { Corps of } \\
\text { Engineers-1 }\end{array}$ \\
\hline \multirow{4}{*}{ LS-1 } & Existing & 5.932 & 6.049 & 6.125 & 6.098 \\
\hline & Water Condition & 6.919 & 6.949 & 7.044 & 7.238 \\
\hline & Seismic Loading (0.32 PGA) & 4.205 & 3.854 & 4.569 & 3.961 \\
\hline & $\begin{array}{c}\text { Extreme }(0.32 \text { PGA + Water } \\
\text { Condition) }\end{array}$ & 4.69 & 4.278 & 5.079 & 4.458 \\
\hline \multirow{4}{*}{ LS-2 } & Existing & 7.11 & 8.48 & 16.81 & 12.57 \\
\hline & Water Condition & 7.20 & 8.37 & 16.86 & 12.31 \\
\hline & Seismic Loading (0.32 PGA) & 5.51 & 5.98 & 5.73 & 8.32 \\
\hline & $\begin{array}{c}\text { Extreme (0.32 PGA + Water } \\
\text { Condition) }\end{array}$ & 5.48 & 5.89 & 5.65 & 8.04 \\
\hline
\end{tabular}

two sites were selected, and geological map was prepared. The rocks exposed on the sites were mainly Slates and phyllites of Salkhala Formation. Discontinuity surveys were conducted on the selected sites. The discontinuity data was used to evaluate the rock quality using Rock Mass Rating $(R M R)$. RMR depicts that rock lies in good category.

Kinematic analysis was performed with computer code DIPS v. 7.0 to assess stability of slopes. At LS-1, plane failure and direct toppling are likely along the joints while there is no possibility of wedge failure. Flexural topping can also be expected at this site. While at LS-2, plane failure is likely along foliation planes and wedge failure can be expected at the intersection of joints of $J 1$ and 2 .

Limit equilibrium analysis was performed with computer code Slide v. 7.0 to assess FOS of slopes at static and pseudo-static conditions. At four various conditions such as dry, wet, seismic loading and extreme, it was revealed that FOS is $>1$ which concluded that there is no possibility of global failure along these slopes.

This study concludes that using empirical classification system, kinematic and limit equilibrium analyses simultaneously, stable slopes can be designed in seismically active regime, however, verification of the results is always emphasised. The results of study verify the study of Palmström and Stille [61], that is the designing of engineering projects should always be related to ongoing stage of the project with ongoing decisions. In the present study the decisions were made by the forward analyses using three different methods which were empirical classification schemes for the rock quality, kinematic analysis for the rock failures and limit equilibrium analyses for the stability of slopes in static and pseudo static conditions as the present study lies in active tectonic regime.

\section{Conflicts of Interest}

The authors have no conflict of interest in this research. 


\section{References}

[1] Tilloy, A., Malamud, B.D., Winter, H. and Joly-Laugel, A. (2019) A Review of Quantification Methodologies for Multi-Hazard Interrelationships. Earth-Science Reviews, 196, Article ID: 102881. https://doi.org/10.1016/j.earscirev.2019.102881 http://www.sciencedirect.com/science/article/pii/S001282521930025X

[2] Assembly UNG (2016) Report of the Open-Ended Intergovernmental Expert Working Group on Indicators and Terminology Relating to Disaster Risk Reduction. United Nations Gen Assembly, New York, 41.

[3] Turner, A.K. and Schuster, R.L. (1996) Landslides: Investigation and Mitigation. Special Report 247. Transportation Research Board, The National Academies Press, Washington DC.

[4] Coppola, D.P. (2006) Introduction to International Disaster Management. Elsevier, Amsterdam.

[5] Van Westen, C.J., Castellanos, E. and Kuriakose, S.L. (2008) Spatial Data for Landslide Susceptibility, Hazard, and Vulnerability Assessment: An Overview. Engineering Geology, 102, 112-131. https://doi.org/10.1016/j.enggeo.2008.03.010

[6] Noor, A., Akram, M.S., Ahmed, L. and Sarwar, W. (2017) Back Analysis of an Earthquake Triggered Landslide in Mansehra District, Pakistan. Journal of Himalayan Earth Sciences, 50, 86-99.

[7] Carlson, D.H., Plummer, C.C. and McGeary, D. (2008) Physical Geology: Earth Revealed. McGraw-Hill, New York.

[8] Akram, M.S., Zeeshan, M., Mirza, K., Ahmed, L., Noor, A. and Ali, M. (2019) Slope Stability Analyses Using Classification Systems and Numerical Methods: Case Study from Lower Dir, Khyber Pakhtunkhwa, Pakistan. Himalayan Geology, 40, 67-77.

[9] Cruden, D.M. (1991) A Simple Definition of a Landslide. Bulletin of the International Association of Engineering Geology, 43, 27-29. https://doi.org/10.1007/BF02590167

[10] Lundgren, L. (1978) Studies of Soil and Vegetation Development on Fresh Landslide Scars in the Mgeta Valley, Western Uluguru Mountains, Tanzania. Geografiska Annaler. Series A, Physical Geography, 60, 91-127. https://doi.org/10.1080/04353676.1978.11879967

[11] Singh, B. and Goel, R.K. (2011) Engineering Rock Mass Classification : Tunneling, Foundations, and Landslides. Butterworth-Heinemann, Oxford.

https://doi.org/10.1016/B978-0-12-385878-8.00011-2

https://books.google.com.pk/books/about/Engineering_Rock_Mass_Classification.h tml?id=7TCQEQ1RXOAC\&redir_esc=y

[12] Price, D.G. (2008) Engineering Geology: Principles and Practice. Springer Science \& Business Media, New York.

[13] Gurocak, Z., Alemdag, S. and Zaman, M.M. (2008) Rock Slope Stability and Excavatability Assessment of Rocks at the Kapikaya Dam Site, Turkey. Engineering Geology, 96, 17-27. https://doi.org/10.1016/j.enggeo.2007.08.005

[14] Qi, C., Wu, J., Liu, J. and Kanungo, D.P. (2016) Assessment of Complex Rock Slope Stability at Xiari, Southwestern China. Bulletin of Engineering Geology and the Environment, 75, 537-550. https://doi.org/10.1007/s10064-015-0763-4

[15] Ikenna Nkpadobi, J., Kuna Raj, J. and Fatt Ng, T. (2016) Classification of Cut Slopes in Weathered Meta-Sedimentary Bedrocks. Earth Sciences Research Journal, 20, 1-9. https://doi.org/10.15446/esrj.v20n2.52781 
[16] Aydan, O. (2006) Geological and Seismological Aspects of Kashmir Earthquake of October 8, 2005 and a Geotechnical Evaluation of Induced Failures of Natural and Cut Slopes. Journal of The School of Marine Science and Technology, 4, 25-44.

[17] Akram, M.S., Ahmed, L., Farooq, S., Ahad, M.A., Zaidi, S.M.H., Khan, M., et al. (2018) Geotechnical Evaluation of Rock Cut Slopes Using Basic Rock Mass Rating (RMR Basic), Slope Mass Rating (SMR) and Kinematic Analysis along Islamabad Muzaffarabad Dual Carriageway (IMDC), Pakistan. Journal of Biodiversity and Environmental Sciences, 13, 297-306.

[18] Hoek, E. and Bray, J.D. (2014) Rock Slope Engineering. CRC Press, London. https://doi.org/10.1201/9781482267099

[19] González de Vallejo, L.I. and Ferrer, M. (2011) Geological Engineering. CRC Press/Balkema, Leiden, 678 p.

https://www.crcpress.com/Geological-Engineering/Vallejo-Ferrer/p/book/97804154 $\underline{13527}$

[20] Kundu, J., Sarkar, K. and Singh, T.N. (2017) Static and Dynamic Analysis of Rock Slope-A Case Study. Procedia Engineering, 191, 744-749. https://doi.org/10.1016/j.proeng.2017.05.240

[21] Smith, J.V. (2016) A Method for Assessing Discontinuity Poles for Potential Wedge Sliding. Engineering Geology, 202, 55-61. https://doi.org/10.1016/j.enggeo.2015.12.025

[22] Wyllie, D.C. and Mah, C. (2014) Rock Slope Engineering. CRC Press, London.

[23] Harp, E.L. and Crone, A.J. (2006) Landslides Triggered by the October 8, 2005, Pakistan Earthquake and Associated Landslide-Dammed Reservoirs. https://doi.org/10.3133/ofr20061052

[24] Owen, L.A., Kamp, U., Khattak, G.A., Harp, E.L., Keefer, D.K. and Bauer, M.A. (2008) Landslides Triggered by the 8 October 2005 Kashmir Earthquake. Geomorphology, 94, 1-9. https://doi.org/10.1016/j.geomorph.2007.04.007

[25] Mahmood, I., Qureshi, S.N., Tariq, S., Atique, L. and Iqbal, M.F. (2015) Analysis of Landslides Triggered by October 2005, Kashmir Earthquake. PLoS Currents, 7.

[26] Hussain, A. (2005) Geology and Tectonics of Northern Pakistan with Respect to October 8, 2005, Earthquake. In: Earthquake Rehabilitation Conference, Seismology, Structures and Codes, Islamabad, 18-19.

[27] Zaré, M. and Karimi-Paridari, S. (2009) An Investigation on Balakot, Muzaffarabad (Pakistan) Earthquake, 8 Oct. 2005, Mw 7.6; Geological Aspects and Intensity Distribution. Journal of Seismology, 13, 327-337. https://doi.org/10.1007/s10950-008-9120-4

[28] Aydan, Ö., Ohta, Y. and Hamada, M. (2009) Geotechnical Evaluation of Slope and Ground Failures during the 8 October 2005 Muzaffarabad Earthquake, Pakistan. Journal of Seismology, 13, 399-413. https://doi.org/10.1007/s10950-008-9146-7

[29] Google Earth (2019) Google Earth. [Online] (7.1.5.1557). https://www.google.com/earth/

[30] Mahmood, I., Kidwai, A.A., Qureshi, S.N., Iqbal, M.F. and Atique, L. (2015) Revisiting Major Earthquakes in Pakistan. Geology Today, 31, 33-38. https://doi.org/10.1111/gto.12085

[31] Bard, J.P. (1980) The Kohistan Sequence: Crust and Mantle of an Island Arc. Proceedings of the International Committee on Geodynamics, 13, 87-93.

[32] Ghazanfar, M. (1991) Geology and Petrotectonics of Southeast Kohistan, Northwest Himalaya, Pakistan. Kashmir Journal of Geology, 8, 67-97. 
[33] Ghazanfar, M. (1993) Petrotectonic Elements and Tectonic Framework of Northwest Himalaya. University of Punjab, Lahore, Gujranwala.

[34] Treloar, P.J., Coward, M.P., Williams, M.P. and Khan, M.A. (1989) Basement-Cover Imbrication South of the Main Mantle Thrust, North Pakistan. Geological Society of America Special Papers, 232, 137-152. https://doi.org/10.1130/SPE232-p137

[35] Anczkiewicz, R., Oberli, F., Burg, J.P., Meier, M., Dawood, H. and Hussain, S.S. (1998) Magmatism South of the Indus Suture, Lower Swat, Pakistan. 13th Himalaya-Karakoram-Tibet International Workshop, Peshawar, Pakistan, 20-22 April 1998, 7-9.

[36] Garrido, C.J., Bodinier, J.-L., Burg, J.-P., Zeilinger, G., Hussain, S.S., Dawood, H., et al. (2006) Petrogenesis of Maficgarnet Granulite in the Lower Crust of the Kohistan Paleo-Arc Complex (Northern Pakistan): Implications for Intra-Crustal Differentiation of Island Arcs and Generation of Continental Crust. Journal of Petrology, 47, 1873-914. https://doi.org/10.1093/petrology/egl030

[37] Heuberger, S., Schaltegger, U., Burg, J.-P., Villa, I.M., Frank, M., Dawood, H., et al. (2007) Age and Isotopic Constraints on Magmatism along the Karakoram-Kohistan Suture Zone, NW Pakistan: Evidence for Subduction and Continued Convergence after India-Asia Collision. Swiss Journal of Geosciences, 100, 85-107. https://doi.org/10.1007/s00015-007-1203-7

[38] Calkins, J.A., Offield, T.W., Abdullah, S.K. and Ali, S.T. (1975) Geology of the Southern Himalaya in Hazara, Pakistan, and Adjacent Areas. U.S. Government Publishing Office, Washington DC. https://doi.org/10.3133/pp716C

[39] Calkins, J.A., Offield, T.W. and Ali, S.T. (1969) Geology and Mineral Resources of Southern Hazara District, West Pakistan and Part of Western Kashmir. United States Department of State and Government of Pakistan Project Report, 43, 92.

[40] Shah, S.M.I. (1977) Stratigraphy of Pakistan. The Geological Survey of Pakistan, 12.

[41] Shah, S.M.I. (2009) Stratigraphy of Pakistan (Memoirs of the Geological Survey of Pakistan). The Geological Survey of Pakistan, 22.

[42] Kazmi, A.H. and Jan, M.Q. (1997) Geology and Tectonics of Pakistan. Graphic Publishers, Karachi, Pakistan.

[43] ISRM (International Society for Rock Mechanics) (1981) Suggested Methods for the Quantitative Description of Discontinuities in Rock Masses. Rock Characterisation, Testing and Monitoring-ISRM Suggested Methods. Pergamon Press, Oxford, 319-368.

[44] Aydin, A. (2008) ISRM Suggested Method for Determination of the Schmidt Hammer Rebound Hardness: Revised Version. In: The ISRM Suggested Methods for Rock Characterization, Testing and Monitoring. 2007-2014, Springer, Amsterdam, 25-33. https://doi.org/10.1007/978-3-319-07713-0_2

[45] Miller, R.P. (1965) Engineering Classification and Index Properties for Intact Rock. PhD Thesis, University of Illinois, Champaign, IL.

[46] Palmström, A. (1982) The Volumetric Joint Count-A Useful and Simple Measure of the Degree of Rock Jointing. Proceedings of 4 th International Association of Engineering Geology, 5, 221-228.

[47] Palmstrom, A. (2005) Measurements of and Correlations between Block Size and Rock Quality Designation (RQD). Tunnelling and Underground Space Technology, 20, 362-377. https://doi.org/10.1016/j.tust.2005.01.005

[48] Palmström, A. and Broch, E. (2006) Use and Misuse of Rock Mass Classification Systems with Particular Reference to the Q-System. Tunnelling and Underground 
Space Technology, 21, 575-593. https://doi.org/10.1016/j.tust.2005.10.005

[49] Brown, E.T. and Hoek, E. (1980) Underground Excavations in Rock. CRC Press, London. https://doi.org/10.1201/9781482288926

[50] Majeed, Y. and Abu Bakar, M.Z. (2015) Kinematic Analysis of Selected Rock Slopes along Choa Saidan Shah-Kallar Kahar Road Section. Journal of Faculty of Engineering \& Technology, 22, 123-135.

[51] Rocscience (2012) DIPS v7.0 Graphical and Statistical Analysis of Orientation Data. Rocscience Inc., Toronto, Ontario.

[52] Bishop, A.W. (1955) The Use of the Slip Circle in the Stability Analysis of Slopes. Geotechnique, 5, 7-17. https://doi.org/10.1680/geot.1955.5.1.7

[53] Janbu, N. (1954) Application of Composite Slip Surface for Stability Analysis. In: Proceedings of European Conference on Stability of Earth Slopes, Sweden, 43-49.

[54] Spencer, E. (1967) A Method of Analysis of the Stability of Embankments Assuming Parallel Inter-Slice Forces. Geotechnique, 17, 11-26. https://doi.org/10.1680/geot.1967.17.1.11

[55] Spencer, E. (1969) Circular and Logarithmic Spiral Slip Surfaces. Journal of Soil Mechanics \& Foundations Div, 95, 227-234.

[56] Deere, D.U. and Miller, R.P. (1966) Engineering Classification and Index Properties for Intact Rock. University of Illinois Urbana-Champaign, Urbana'and Champaign, IL.

[57] Bieniawski, Z.T. (1973) Engineering Classification of Jointed Rock Masses. Transaction of the South African Institution of Civil Engineers, 15, 335-344.

[58] Bieniawski, Z.T. (1974) Geomechanics Classification of Rock Masses and Its Application in Tunneling. In: Proceedings of $3 \mathrm{rd}$ International Congress on Rock Mechanics, II-A.

[59] Bieniawski, Z.T. (1976) Rock Mass Classification in Rock Engineering Applications. In: Proceedings of a Symposium on Exploration for Rock Engineering, 97-106.

[60] Bieniawski, Z.T. (1989) Engineering Rock Mass Classifications: A Complete Manual for Engineers and Geologists in Mining, Civil, and Petroleum Engineering. John Wiley \& Sons, New York.

[61] Palmström, A. and Stille, H. (2007) Ground Behaviour and Rock Engineering Tools for Underground Excavations. Tunnelling and Underground Space Technology, 22, 363-376. https://doi.org/10.1016/j.tust.2006.03.006 